Trinity College

Trinity College Digital Repository

1906

\title{
An act creating a United States court for China and prescribing the jurisdiction thereof.
}

United States

Follow this and additional works at: https://digitalrepository.trincoll.edu/eastbooks

\section{Recommended Citation}

United States, "An act creating a United States court for China and prescribing the jurisdiction thereof." (1906). East Collection. 48.

https://digitalrepository.trincoll.edu/eastbooks/48

This Article is brought to you for free and open access by the Library Digital Collections at Trinity College Digital Repository. It has been accepted for inclusion in East Collection by an authorized administrator of Trinity College Digital Repository. 
Trinity LSF

Academic

Scholars'

Trust

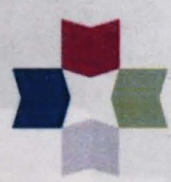

AC

901

M6

no. 143 


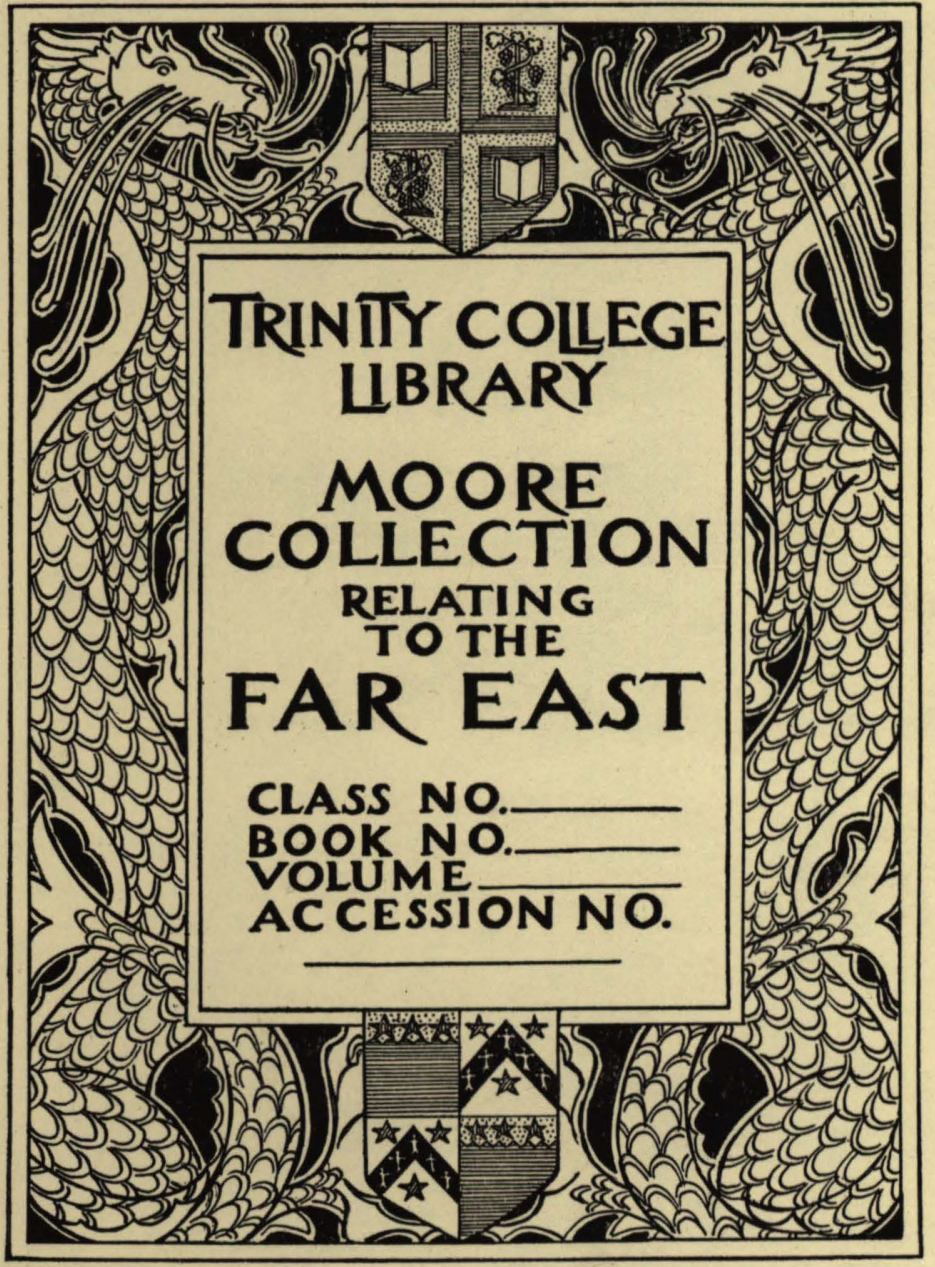




\section{[PUBLIC-No. 403.]}
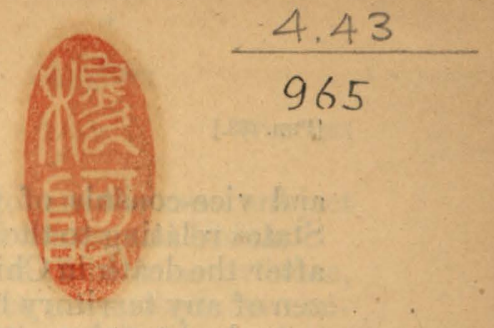

jurisdiction thereof.

An Act Creating a United States court for China and prescribing the

Be it enacted by the Senate and House of Representatives of the United States of America in. Congress assembled, That a court is hereby established, to be called the United States court for China, which shall have exclusive jurisdiction in all cases and judicial proceedings whereof jurisdiction may now be exercised by United States consuls and ministers by law and by virtue of treaties between the United States and China, except in so far as the said jurisdiction is qualified by section two of this Act. The said court shall hold sessions at Shanghai, China, and shall also hold sessions at the cities of Canton, Tientsin, and Hankau at stated periods, the dates of such sessions at each city to be announced in such manner as the court shall direct, and a session of the court shall be held in each of these cities at least once annually. It shall be within the power of the judge, upon due notice to the parties in litigation, to open and hold court for the hearing of a special cause at any place permitted by the treaties, and where there is a United States consulate, when, in his judgment, it shall be required by the convenience of witnesses, or by some public.interest. The place of sitting of the court shall be in the United States consulate at each of the cities, respectively.

That the seal of the said United States court for China shall be the arms of the United States, engraved on a circular piece of steel of the size of a half dollar, with these words on the margin, "The Seal of the United States Court for China."

The seal of said court shall be provided at the expense of the United States.

All writs and processes issuing from the said court, and all transcripts, records, copies, jurats, acknowledgments, and other papers requiring certification or to be under seal, may be authenticated by said seal, and shall be signed by the clerk of said court. All processes issued from the said court shall bear test from the day of such issue.

SEC. 2. The consuls of the United'States in the cities of China to which they are respectively accredited shall have the same jurisdiction as they now possess in civil cases where the sum or value of the property involved in the controversy does not exceed five hundred dollars United States money and in criminal cases where the punishment for the offense charged can not exceed by law one hundred dollars fine or sixty days' imprisonment, or both, and shall have power to arrest, examine, and discharge accused persons or commit them to the said court. From all final judgments of the consular court either party shall have the right of appeal to the United States court for China: Provided, also, That appeal may be taken to the United States court for China from any final judgment of the consular courts of the United States in Korea so long as the rights of extraterritoriality shall obtain in favor of the United States. The said United States court for China shall have and exercise supervisory control over the discharge by consuls 
and vice-consuls of the duties prescribed by the laws of the United States relating to the estates of decedents in China. Within sixty days after the death in China of any citizen of the United States, or any citizen of any territory belonging to the United States, the consul or viceconsul whose duty it becomes to take possession of the effects of such deceased person under the laws of the United States shall file with the clerk of said court a sworn inventory of such effects, and shall as additional effects come from time to time into his possession immediately file a supplemental inventory or inventories of the same. He shall also file with the clerk of said court within said sixty days a schedule under oath of the debts of said decedent, so far as known, and a schedule or statement of all additional debts thereafter discovered. Such consul or vice-consul shall pay no claims against the estate without the written approval of the judge of said court, nor shall he make sale of any of the assets of said estate without first reporting the same to said judge and obtaining a written approval of said sale, and he shall likewise within ten days after any such sale report the fact of such sale to said court and the amount derived therefrom. The said judge shall have power to require at any time reports from consuls or vice-consuls in respect of all their acts and doings relating to the estate of any such deceased person. The said court shall have power to require where it may be necessary a special bond for the faithful performance of his duty to be given by any consul or vice-consul into whose possession the estate of any such deceased citizen shall have come in such amount and with such sureties as may be deemed necessary, and for failure to give such bond when required, or for failure to properly perform his daties in the premises, the court may appoint some other person to take charge of said estate, such person having first given bond as aforesaid. A record shall be kept by the clerk of said court of all proceedings in respect of any such estate under the provisions hereof.

SEc. 3. That appeals shall lie from all final judgments or decrees of said court to the United States circuit court of appeals of the ninth judicial circuit, and thence appeals and writs of error may be taken from the judgments or decrees of the said circuit court of appeals to the Supreme Court of the United States in the same class of cases as those in which appeals and writs of error are permitted to judgments of said court of appeals in cases coming from district and cireuit courts of the United States. Said appeals or writs of error shall be regulated by the procedure governing appeals within the United States from the district courts to the circuit courts of appeal, and from the circuit courts of appeal to the Supreme Court of the United States, respectively, so far as the same shall be applicable; and said courts are hereby empowered to hear and determine appeals and writs of error so taken.

SEC. 4. The jurisdiction of said United States court, both original and on appeal, in civil and criminal matters, and also the jurisdiction of the consular courts in China, shall in all cases be exercised in conformity with said treaties and the laws of the United States now in force in reference to the American consular courts in China, and all judgments and decisions of said consular courts, and all decisions, judgments, and decrees of said United States court, shall be enforced in accordance with said treaties and laws. But in all such cases when such laws are deficient in the provisions necessary to give jurisdiction or to furnish suitable remedies, the common law and the law as established by the decisions of the courts of the United States shall be 
applied by said court in its decisions and shall govern the same subject to the terms of any treaties between the United States and China.

SEc. 5. That the procedure of the said court shall be in accordance, so far as practicable, with the existing procedure prescribed for consular courts in China in accordance with the Revised Statutes of the United States: Provided, however, That the judge of the said United States court for China shall have authority from time to time to modify and supplement said rules of procedure. The provisions of sections forty-one hundred and six and forty-one hundred and seven of the Revised Statutes of the United States allowing consuls in certain cases to summon associates shall have no application to said court.

SEc. 6. There shall be a district attorney, a marshal, and a clerk of said court, with authority possessed by the corresponding officers of the district courts in the United Stàtes as far as may be consistent with the conditions of the laws of the United States and said treaties. The judge of said court and the district attorney, who shall be lawyers of good standing and experience, marshal, and clerk shall be appointed by the President, by and with the advice and consent of the Senate, and. shall receive as salary, respectively, the sums of eight thousand dollars per annum for said judge, four thousand dollars per annum for said district attorney, three thousand dollars per annum for said marshal, and three thousand dollars per annum for said clerk. The judge of the said court and the district attorneys shall, when the sessions of the court are held at other cities than Shanghai, receive in addition to their salaries their necessary expenses during such sessions not to exceed ten dollars per day for the judge and five dollars per day for the district attorney.

SEC. 7. The tenure of office of the judge of said court shall be ten years, unless sooner removed by the President for cause; the tenure of office of the other officials of the court shall be at the pleasure of the President.

SEC. 8. The marshal and the clerk of said court shall be required to furnish bond for the faithful performance of their duties, in sums and with sureties to be fixed and approved by the judge of the court. They shall each appoint, with the written approval of said judge, deputies at Canton and Tientsin, who shall also be required to furnish bonds for the faithful performance of their duties, which bonds shall be subject, both as to form and sufficiency of the sureties, to the approval of the said judge. Such deputies shall receive compensation at the rate of five dollars for each day the sessions of the court are held at their respective cities. The office of marshal in China now existing in pursuance of section forty-one hundred and eleven of the Revised Statutes is hereby abolished.

SEC. 9. The tariff of fees of said officers of the court shall be the same as the tariff already fixed for the consular courts in China, subject to amendment from time to time by order of the President, and all fees taxed and received shall be paid into the Treasury of the United States.

Approved, June 30, 1906. 


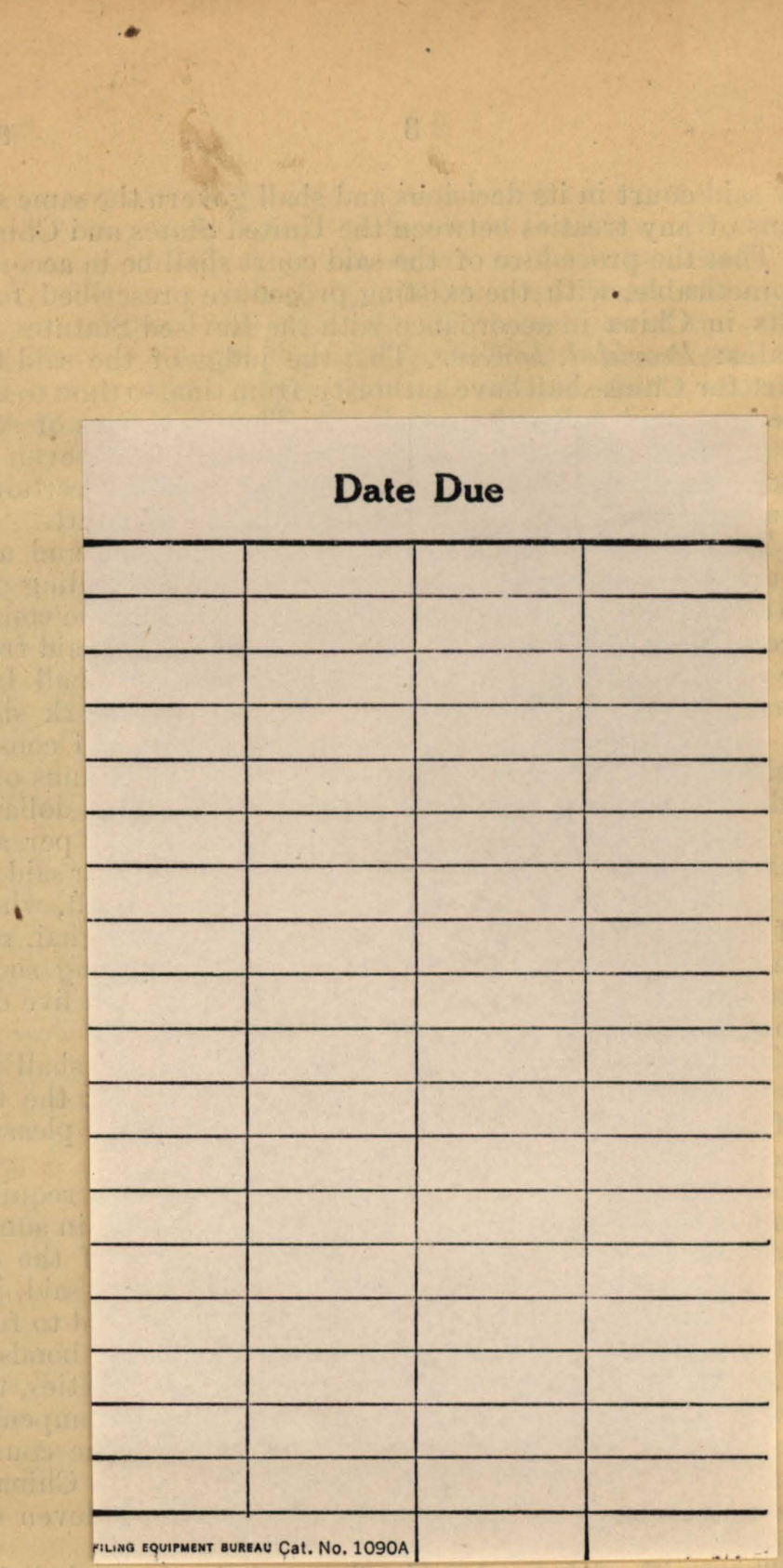




\section{Photomount}

Pamphlet

Binder

Gaylord Bros.

Makers

Syracuse, $N$. Y. PAI. JAS 21, 1908 
